Article

\title{
From Neoclassical Economics to Common Good Economics
}

\author{
Johannes Dolderer ${ }^{1}$, Christian Felber ${ }^{2, *}$ and Petra Teitscheid ${ }^{3}$ \\ 1 Economy for the Common Good Baden-Wuerttemberg Association, c/o Impact Hub Stuttgart, \\ Quellenstraße 7a, 70376 Stuttgart, Germany; johannes.dolderer@ecogood.org \\ 2 IASS Potsdam, Berliner Straße 30, 14467 Potsdam, Germany \\ 3 Institute of Sustainable Nutrition, University of Applied Sciences Münster, Corrensstr. 25, \\ 48149 Münster, Germany; petra.teitscheid@fh-muenster.de \\ * Correspondence: christian.felber@iass-potsdam.de
}

Citation: Dolderer, J.; Felber, C.; Teitscheid, P. From Neoclassical Economics to Common Good Economics. Sustainability 2021, 13, 2093. https://doi.org/10.3390/ su13042093

\section{Academic Editor:}

Vanessa Campos-Climent

Received: 31 December 2020

Accepted: 10 February 2021

Published: 16 February 2021

Publisher's Note: MDPI stays neutral with regard to jurisdictional claims in published maps and institutional affiliations.

Copyright: (c) 2021 by the authors. Licensee MDPI, Basel, Switzerland. This article is an open access article distributed under the terms and conditions of the Creative Commons Attribution (CC BY) license (https:// creativecommons.org/licenses/by/ $4.0 /)$.

\begin{abstract}
The economy for the common good (ECG) has been developed as a practical economic model, starting in Austria, Bavaria, and South Tyrol in 2010. Nowadays, ECG is considered a viable approach for sustainable transformation across Europe, and also worldwide. Within economic policy, ECG expands social market economy concepts; from a theoretical perspective of economics the question arises, of whether the implicit theoretical model refines the neoclassical paradigm or actually transcends it. During the first scientific conference on the ECG, at the end of 2019 at the University of Applied Sciences Bremen, some 150 participants concluded that an investigation of ECG practices was necessary, and that the fundamental theory needs to be developed in an explicit and systematic way. This article is a first attempt at contrasting the theoretical basis of the ECG model with neoclassical economics, using core concepts and cornerstones of the latter's paradigm. The outcome is the cornerstone of common good economics.
\end{abstract}

Keywords: heterodox economics; neoclassical economics; economy for the common good; common good economics; market economy; welfare

\section{Introduction}

In the current economic system, growth in the quantity of goods produced (in conjunction with technological innovations, rising labor productivity, and international division of labor) is seen as the solution to many social challenges. This has been supported by the neoclassical economic theory, explaining welfare mainly by growing market activities. Since the 1980s, however, it has been clear that the successful model of global economic growth, in addition to creating material prosperity and improving living conditions for many people, also comes at a very high price. Foremost among these is the massive degradation of global ecosystems. Man-made global changes such as climate change, loss of biodiversity, soil degradation, and nitrification are causing irreversible damage that is deeply affecting the identity and structure of human societies, and significantly threatening the foundations of life for future generations [1].

The development of prosperity is also accompanied by extreme inequality. While the lives of 265 million humans will be at risk due to acute hunger by the end of 2020 [2], and 50 percent of the population in Germany own just 1.3 percent of the country's net wealth [3], the richest people in the world have assets in the range of triple-digit billions. The highest known incomes in Germany are 60,000 times the lowest known incomes, in the USA even 360,000 times [4]. Inequality endangers social cohesion and the functioning of societies. According to research by Richard Wilkinson, if the level of income inequality in the US were reduced to that of Japan, Norway, Sweden, or Finland, "the proportion of Americans who believe they can trust others would increase by 75 per cent. The rates of people with mental disorders or obesity could each fall by two-thirds, the number of teenage pregnancies could be halved, the prison population could fall by 40 per cent." In addition, people would live longer and have to work the equivalent of two months less 
each year [5]. Psychology research studies have that the pursuit of materialistic values makes people less happy and free [6]. It is precisely the affluent societies that suffer from a loss of meaning and inner wealth. In summary, it can be stated that prosperity (measured in terms of materiality and finances) is higher than ever before, and yet at the same time quality of life and wellbeing are declining, and threatened from a long-term perspective.

These ecological and social imbalances are both a challenge and an opportunity for economists to reexamine what exactly the objectives and goals of economic activity are. Additional questions are raised on how prosperity and comprehensive wealth should be defined and measured precisely, and whether it can be created, protected, or increased with the same analysis, strategies, and means as before. Specifically, the authors of this article ask whether the neoclassical interpretation of economics, practiced worldwide, is capable of meeting these challenges, or whether alternative concepts, such as the economy for the common good, offer more appropriate answers.

Neoclassical economics looks back on a 150-year academic tradition, and is taught at most economics faculties that are the foundation of economic policy and action worldwide. Even if the definition of neoclassical economics can be discussed in detail [7], some undisputed core elements are methodological individualism, rationality, and general equilibrium of markets [8,9]. In section three we will explicate in more detail our view of what constitutes neoclassical theory.

Meanwhile, neoclassical economics have been under massive criticism. This has generated a wide field of alternative, heterodox economic theories, and the call for a transformative, pluralistic economic science, being committed to principles such as transparency, reflexivity, value-orientation, participation, and plurality [10].

The economy for the common good (ECG), on the other hand, has been developed as a practical economic model. It started in Austria, Bavaria, and South Tyrol in 2010. Nowadays, the ECG is considered a viable approach for sustainable transformation across Europe, and also worldwide. The theoretical superstructure of the economy for the common good draws on interdisciplinary insights from ethics, ecology, political science, social psychology, neurobiology, systems theory, pedagogy, and others, but has not yet claimed to be a new, heterodox, economic theory.

In this article, we pursue three goals: First, for the first time, we aim at making the theoretical assumptions of the ECG model systematically explicit, defining "common good economics". This states a theoretical ground for the practical conclusions of the ECG model. This theory will, second, be compared with neoclassical economics on an equal footing. As a consequence, the ECG model should become part of a broader scientific discourse and both discussion of, and research on, it will be fostered. The final and third goal behind this exercise is to contribute to an economic model which is realistic enough to cope with the challenges of mankind in the 21st century.

\section{Materials and Methods}

The following definition of common good economics and its comparison with neoclassical economics is an intermediate result of a long standing, general examination of economic theory and practice. Accordingly, we present a comprehensive theoretical research with a comparative analysis. As step one of our procedure, we used three general sources for the theoretical examination:

(a) We used the most widely used introductory textbooks on economics to grasp the "paradigm" they are disseminating: Samuelson/Nordhaus, Mankiw/Taylor, Varian, Pindyck/Rubinfeld, and Van Suntum. For the sake of a historical understanding we also examined some of Walras', Menger's, and Jevon's work, who are considered to be the founders of neoclassical economic theory.

(b) We examined the literature which represents alternative, heterodox economic perspectives, and thereby a critique of neoclassical economics, with a focus on textbooks. The literature covers a wide range of theories and critiques. Amongst these are both entire economic paradigms, such as ecological economics [11], doughnut eco- 
nomics [12], or sustainable economics [13], as well as rather particular theoretical contributions, such as from Keen, Stiglitz, Ötsch, Göpel, and Komlos. We also read some "non-economists" who have contributed interdisciplinary insights, part of which are evidence-based, instead of assumption-based, e.g., Claus Dierksmeier and Michael Pirson (philosophy), Alfie Kohn (social psychology), Tim Kasser (psychology), Johan Rockström et al. (earth system science), Hans-Peter Dürr (physics), and Joachim Bauer (neurobiology).

(c) Finally, we referred to the alternative economic ECG model as published by Felber [14], and online by the civic ECG movement [15].

In a second step, we elaborated a comparative matrix of the neoclassical mainstream paradigm in order to contrast it to our theoretical assumptions and practical conclusions in the context of the ECG model. This matrix is structured in four sections: philosophy of science; definition and goals of the economy and economics; basic elements of the economy; and welfare and market economy. This structure tries to grasp the most relevant categories of both the neoclassical paradigm and the ECG paradigm, in order to, first, compare their essence, and second, track potential evolutions from the first to the second. All sections are further subdivided in two to seven categories, as shown in Table 1.

Table 1. Structure of the methodological comparison between neoclassical economics and common good economics, leading to practical conclusions for the ECG model.

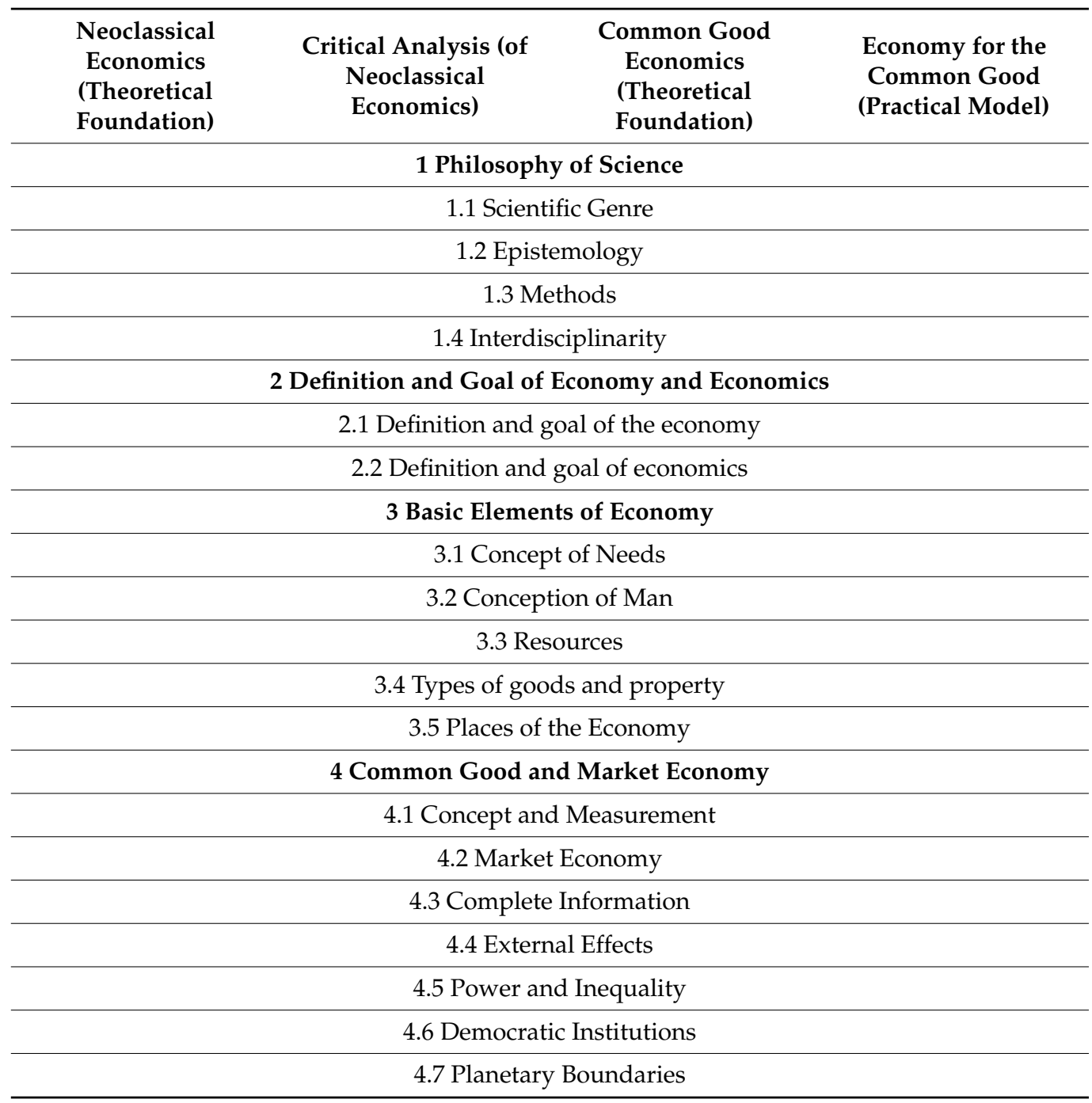


In each section, we described briefly the essence of the existing neoclassical paradigm we found in current textbooks and historical sources, we synthesized existing critique with our own criticism of it, and contrasted it with the approach of the economy for the common good. Thereby, the most important implicit theoretical assumptions underlying the practical ECG model are made more explicit, defining for the first time a systematic "common good economics" (step 3 of our research process). Moreover, these theoretical assumptions are linked to theoretical assumptions found in the field of heterodox economics. In a forth step, we related the theoretical foundation of common good economics with the practical ECG model. This means that we derived practical conclusions from the theory and, vice versa, embedded some practical ideas into the theory. The results are summarized in a table at the end of the next chapter (see Figure 1).

(1) Review of literature
(a) Neoclassical economics:
- introductory text books
- historical publications

(b) critique of neoclassical economics along with: - heterodox economic theories - interdisciplinary (non-economist) theories

(c) ECG model

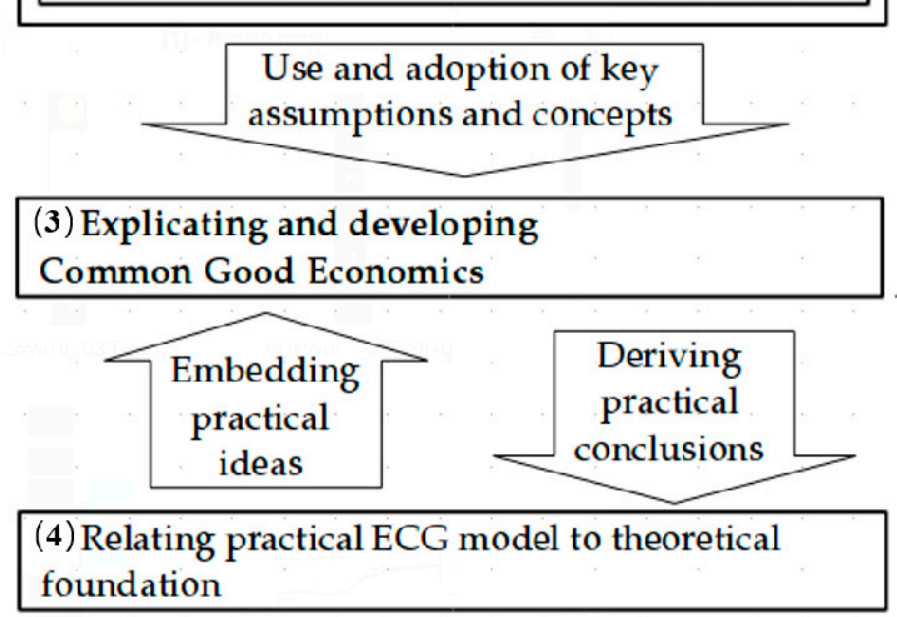

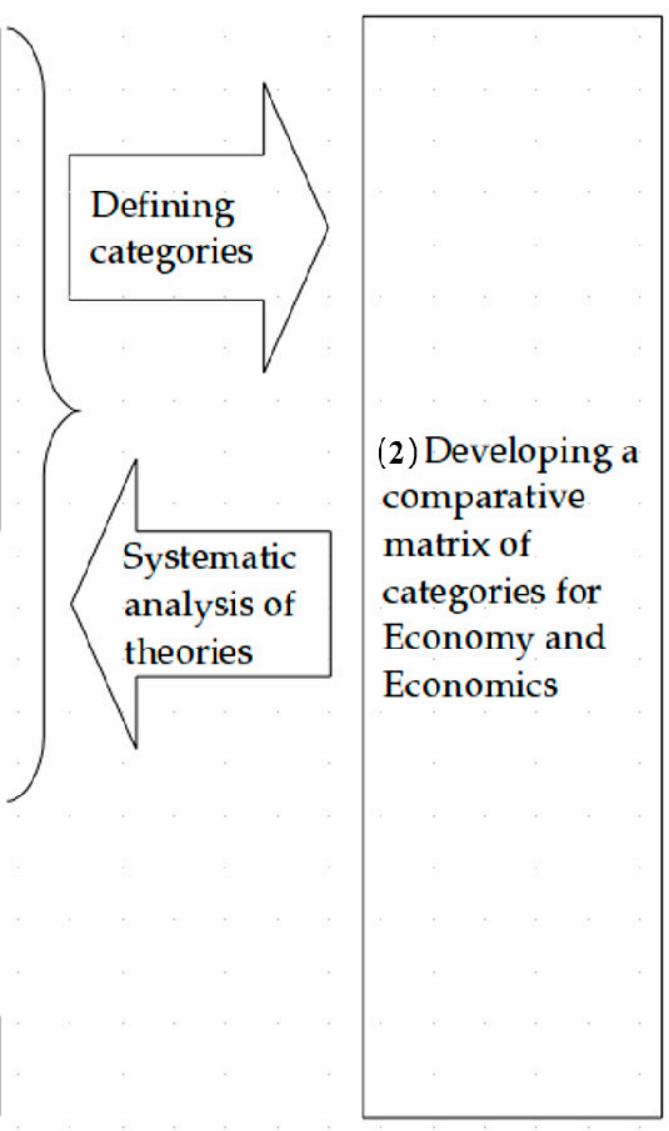

Figure 1. The research framework, showing the four steps of procedure and the relations in between.

\section{Results}

Our procedure was to work systematically through the comparative paradigm matrix.

\subsection{Philosophy of Science}

\subsubsection{Scientific Genre}

In the view of common good economics, economics is a social science and not a natural science. Many economists probably believe that the latter also applies to neoclassical economics. However, the case is not so clear-cut: the world's most widely used introductory textbook on economics states: "Economics proceeds dispassionately like a natural science. By applying scientific methods to political questions, economics seeks to make progress on the fundamental issues" [16]. The authors are not outliers in this regard. The classification of the neoclassical school of theory as a natural science goes back to one of its founders, Leon Walras: "Pure economic theory is a science similar in every aspect to the physicomathematical sciences" [17]. Maurice Allais wrote a hundred years later that economic 
phenomena are as regular "as those found in physics" [18]. Milton Friedman was convinced that "positive economics is, or can be, an objective" science, in precisely the same sense as any of the physical sciences" [19]. Doubts about this approach crept into Thomas Straubhaar's mind in 2018: “Through mathematisation, we have increasingly wanted to turn economics into a natural science and in doing so have probably overestimated our possibilities" [20].

In line with physics, neoclassical economics justifies its theory building with corresponding language. Samuelson/Nordhaus write about "enduring truths" [21] of economics, Mankiw/Taylor of "principles" (like Newton) [22](p. 3), whereas "market laws" and "market mechanism" have become widespread even in common parlance.

From the perspective of the economy for the common good, these mechanistic metaphors are inappropriate because economy and markets are not natural phenomena but social constructions. They can therefore neither be described appropriately with "truth" nor with "laws". Empirically, it is well known that demand can rise, fall, or remain constant when prices fall [23].

The emergence of certain patterns depends on cultural values, regulating institutions, and individual preferences, which are not fixed but variable. ECG therefore prefers the terms market design and game rules in economic policy.

\subsubsection{Epistemology}

In line with physics, neoclassical economics chooses the epistemic approach of positivism, and claims to be a completely objective and value-free science. However, the idea of pure objectivity ignores the reflexivity, pre-analytical vision [24], and selective perception of the scientists. Common good economics therefore emphasizes the role of self-reflection and, besides other things, builds on pragmatism as well.

Positive economists like Friedman assert: "Positive economics is in principle independent of any particular ethical position or normative judgments" [19]. This attitude ignores the ethical bias and cultural imprints of the scientists. By definition, a social science is driven by and concerned with values just like every action of humans. Paul Komlos writes: "Economics cannot be practised in a value-free way today (...) Our political, moral and philosophical sympathies influence our basic assumptions ( . . ) Our conclusions are derived mainly from assumptions, intuitions, introspection, opinion and, yes, ideology" [25]. Claiming value-free economics is distracting from the underlying values, and therefore leads to an hidden, manipulative normativity. For instance, the operationalization of rationality as endless profit maximization implies values of materialism and selfishness.

Consequently, economics of the common good demand critical self-reflection and even more importantly, full transparency about the values of scientists and economic paradigms. The ECG model acknowledges its ethical foundation, turning it into its strongest argument: Economic activities should align with democratically defined values, such as human dignity, solidarity, and sustainability. This view is supported by John Maynard Keynes' insight: "Economics is essentially a moral science" [26].

\subsubsection{Methods}

Neoclassical economics prefers "formal" mathematical and econometric models, on the grounds of the assumed "exactness" of these methods [27]. These models are based entirely on assumptions, the choice of which is decisive: As Stiglitz put it bluntly, "assumptions matter" [28]: The current dynamic stochastic general equilibrium (DSGE) models did not include banks until 2008, which was one reason why they did not predict the financial crisis. Now there are attempts to supplement the models selectively; however, they still remain oblivious to nature, for example, and no attempt is made to incorporate planetary boundaries [29] into the modeling, which fuels the fear that unforeseen events will once again take economists by surprise.

The ECG relies on methodological diversity. This can include mathematical models, but does not have to. In addition to social science methods, such as historical, case, 
or country studies, in-depth-interviews or conceptual deconstruction and intuition are also approaches to uncover relevant factors. The motif "close contact with reality" is understood as a transdisciplinary approach: science should leave the ivory tower and enter into a relationship with those affected.

A second often repeated criticism of neoclassical modeling is its linear thinking, such as the "methodological individualism". For a very long time, (assumed) individual preferences were just aggregated on the macrolevel, as if there was only one consumer and as if all consumers had the same preferences. By contrast, system theory teaches that the whole is more than the mere sum of its elements. On the "system level", new and unpredicted properties may emerge. To stabilize a system, system designers have to be aware of potential "positive feedback mechanisms", and apply "negative feedback mechanisms" in order to maintain the equilibrium of the whole. Ironically, the core of the neoclassical theory is the general equilibrium which is assumed to establish itself. From the view of the ECG, this belief leads to multiple disequilibria: destruction of the ecological foundations of life, rising inequality in society, instable financial markets, trade imbalances, and inequality within societies and between countries, as well as progressive power concentration between individuals and companies. The ECG approach is to apply negative feedback mechanisms in order to achieve and maintain equilibria in all these fields. The "general equilibrium" ECG heads for is not set by nature, and it includes nature, distribution, power, gender, financial markets, and global trade relations [30] (p. 42-44).

\subsubsection{Inter- and Trans-Disciplinarity}

Neoclassical economics is criticized for being self-related and even "autistic" [31]. According to a study, (mainstream) economics is the only discipline in which a majority of followers disagree with the statement "Interdisciplinary knowledge is generally better than knowledge from only one scientific discipline". While 68 percent of historians, 73 per cent of sociologists, and 79 per cent of psychologists agree, 57 percent of economists reject this [32]. Paul Komlos criticizes that "alternative theories and facts from other disciplines are not considered" in mainstream economics: "Is it permissible in chemistry to suppress relevant results from physics in their own research? Certainly not! But economists regularly disregard results from psychology, sociology, political science and their sister disciplines" [33]. According to Andrew Oswald and Nicolas Stern, "the Quarterly Journal of Economics, the most-cited journal in economics, has never published an article on climate change" [34]. By contrast, the theoretical foundation of the ECG model is highly inter- and trans-disciplinary, it uses findings and theories from the most diverse "branches" of the "tree" of science, which, by nature, is inter- and trans-disciplinary. From a methodological point of view, the ECG sees the risk of producing both irrelevant and harmful knowledge if a scientific discipline is not connected with others and the whole: the "universal science" [35] (p. 255-268).

\subsection{Definition and Goals of the Economy and Economics}

At the very foundation of economics lies the question regarding the purpose of economic activity. While the fathers of neoclassicism, Jevons, Menger, and Walras, still explicitly name human needs and their fulfilment for this purpose, the purpose of economics is not clearly defined in the current mainstream economic literature. The most common definition, which is descriptively about "efficient management of scarce resources", does not include an explicit goal, as efficiency (causa efficiens) always needs a purpose which it serves (causa finalis). In neoclassical textbooks, the concept of needs is implicitly assumed or described as "what people want to have" [36](p. 2). With regard to the overall social purpose of an economy, various ideals circulate: from the greatest possible happiness of the greatest possible number, to the maximization of the benefits of individuals, to the welfare of society as a whole.

The economy for the common good is explicitly and unequivocally committed to the goal of satisfying needs from a long-term societal and ecological perspective. Conceptually, 
it follows a long historical tradition that the economy as a whole must serve the common good. Claus Dierksmeyer's finding is: "From Aristotle via Thomas Aquinas, up to and including Adam Smith, there was a consensus that both economic theory and practice needed to be legitimated as well as limited by a certain overarching goal (Greek: telos) such as the "common good" [37]. The same goal is confirmed by current constitutions: "All economic activity serves the common good", reads Article 151 of the Bavarian constitution. The German Basic Law states that property entails obligations and should "serve the common good" (Art. 14). The Colombian constitution says: "Economic activity and private initiative are free, within the boundaries of the common good." (Art. 333) Are welfare and common good synonyms? Ultimately, it is the concrete operationalization that is decisive here. The economy for the common good works with a formal concept of the common good, meaning that the concrete operationalization must be democratically defined. According to current scientific knowledge, there is much to suggest that an appropriate concept of the common good should, and will, also include non-market aspects as well as long-term resource stocks [38].

Once this exercise is done, a possible definition of "common good economics" could be "the science of the satisfaction of the needs of living and future human generations, in alignment with democratic values and ecological planetary boundaries" [39].

\subsection{Basic Elements of the Economy \\ 3.3.1. Concept of Needs}

A fundamental difference lies in the concept of needs and how such needs are met. Neoclassical economics start from "needs and wants" [40] (p. 127), but ostensibly operates with utility and preference concepts. So, needs are not well-defined. Instead, by applying the concept of consumer sovereignty, the question of need satisfaction is exclusively entrusted to the consumer's decisions [41] (p. 231-233). Preferences indicate utility, which in turn means "need satisfaction" [42] (p. 137). Therefore, neoclassical economics bases preference "on the behavior of the consumer" in decision-making situations [43], and consequently all consumption actions in markets are considered as need satisfaction. In combination with the assumption that "people prefer to consume more to less" [44] (p. 130), this gives rise to the false conclusion that there is an infinite number of needs [45].

ECG, on the other hand, explicitly distinguishes a) needs, from b) strategies for their fulfilment [46-48]. "Preferences" correspond to the latter and are partly socialized, and thus variable. For example, buying a garment is a strategy for fulfilling the need for warmth and protection. The same need would be satisfied if a garment were knitted by grandparents. While needs are considered to be quantitatively limited, fulfilment strategies are not. Different needs can also be behind one and the same strategy, for example, the need for social recognition can also be behind the purchase of clothes. In today's economy, product advertising often aims to unconsciously link market offers with promises of need fulfillment in order to trigger more consumer actions (e.g., buying trendy clothes). Social recognition, however, could be fulfilled more psychologically efficiently, such as through intellectual ability, responsible action, or stable relationships. Measured against the actual need, consumption is often an inefficient and irrational strategy that can sometimes lead to health damage, for example with sugar, alcohol, or stress with too many things and shopping addiction, and even to the unfulfillment of the actual need, such as social recognition.

Manipulative advertising is commonplace in today's economy, and has a positive impact on gross domestic product (GDP), but it lowers the quality of life, wastes resources, and increases the inefficiency of the market economy. Consequently, a clearer and more differentiated definition of needs and, consequently, welfare is necessary to assess the efficiency and success of a market economy. 


\subsubsection{Conception of Man}

With homo economicus, neoclassical economics offers the model of a rational, utilitymaximizing human being and, with a monetary operationalization, suggests that their character is composed of the calculable components of "self-interest", "short-term perspective", and "immediate expediency", with a tendency towards "materialism". The underlying "methodological individualism" and "rationality concept" mark some of the fundamental axioms of neoclassical economics [8], and consider decisions of individuals as being made completely independently of other people's needs [49] (p. 128). By contrast, altruistic behavior tends to be interpreted as irrational. By doing so, neoclassical economics ignores social norms, and society being more than the mere sum of its individual members. As early as 1977, Amartya Sen criticized "the purely economic man" as "close to being a social moron" [50].

ECG does not deny the possibility of pure purpose-rational action, but it uses a more differentiated view of human beings, and also integrates value-rational, traditional, and affective action [51]. With this conception of man, culture, socialization and norms take on a decisive role, and both altruistic and ecologically responsible behavior can be demonstrated and justified. Non-mainstream thinkers have presented accordingly their concepts of, e.g., a "homo politicus" [52], "homo communitas" [53], "homo corporativus" [54], or "homo sustinens" [55]. Economics itself provides a strong example of the role of socialization in shaping decision-making patterns. Through claiming rationality as a undisputable axiom, and at the same time establishing an materialistic, monetary, and selfish operationalization of rationality, neoclassical economics heavily influences students and society in general: Among economics students, willingness to cooperate and empathy decrease in the course of their studies [56] (p. 115f). Contrary to the positivist self-image of neoclassical economics, its model assumptions have a normative effect [57] (p. 100).

Against this background, the ECG approach considers the interdisciplinary and epistemic questioning of the assumptions of neoclassical economics in economic education as essential. For ECG, education for sustainable development, business ethics, as well as the humanistic empowerment to reflect on one's own needs and strategies for their fulfilment, play critical roles, as these capacities provide new freedoms to act.

\subsubsection{Resources and Capital}

When considering resources as factors for economic production, neoclassical economics focuses on produced capital, labor, and land, while social capital and other natural resources are neglected [58] (p. 176). Besides, neoclassical economics to a high degree relies on the substitutability between different kinds of resources, such as natural capital and produced capital. As a result, functional hierarchies between natural, social, and produced capital are underestimated, just like, e.g., ecological or distributive tipping points.

Conversely, ECG is based on more holistic models that also integrate natural capital, human capital, and social capital, and only consider them substitutable to a limited extent [59].

\subsubsection{Types of Goods and Property}

Even though neoclassical economics knows of non-market issues, it suggests that "most goods are private goods" and concludes "Markets are usually a good way to organize economic activity" [60] (p. 304). Apparently public and common goods are considered minor issues.

Common good economics, in the light of growing pressure on natural resources, recognizes many public and common goods. As a consequence, multiple types of property are necessary in an ECG, such as public property, and local commons, as well as usage rights of nature, and private goods. 


\subsubsection{Places of the Economy}

From human needs and the efficient use of resources, neoclassical economics quickly moves to markets as places of need satisfaction. Markets are analyzed as the primary object of economics. This is compatible with the positivist claim, because market activities can be well analyzed quantitatively: as costs, prices, profit, and (financial) capital.

Nevertheless, with its market-focused perspective, neoclassical economics systematically overlooks large areas of need satisfaction, and resource management, and thus of the economy in principle. It also ignores non-market forms of work such as domestic, care, education, and voluntary work, which contribute to the success of society in a similar way to gainful employment.

Therefore, common good economics takes a broader perspective from the outset and emphasizes that human needs can also be satisfied beyond markets, i.e., in households, neighborhoods, through commons, and public goods [61]. Furthermore, essential resources are not necessarily organized through market transactions: from successful relationships to public security and ecosystem services [62].

Consequently, it considers all places of need satisfaction, because this: (a) makes it possible to clarify in an open-ended way which needs can be satisfied most effectively in which places; (b) prevents the danger that the focus on only one place devalues other places and the cultural practices cultivated there, such as volunteering, gift giving, caring, or commoning; and (c) the economic measurement of success can take into account all forms of capital and all satisfied needs.

It is important to note in this context that the market and non-market aspects of need satisfaction are closely interwoven and their analytical separation does not make sense. For example, food as a final product may be obtained through market transactions, but soil fertility, air quality, or climate stability play a key role in the value creation process. Social cohesion and trust can also be influenced by income distribution or the working climate. Moreover, "human resources" are carried, born, and nursed for free by mothers; volunteers rescue them in accidents; and strangers give them life-saving blood. All this is basic need satisfaction, thus economy, but it happens outside markets defined through monetary transactions.

\subsection{Welfare and Market Economy}

\subsubsection{Concept and Measurement of Welfare/Common Good}

The question of how to measure welfare or satisfied need, respectively, is one of the most decisive questions in economics. Through deductive thinking, neoclassical economics defines welfare by preferences expressed through market transactions. This method not only lacks the legitimation of the subjects regarded. In defining welfare this way, neoclassical economics is subject to a three-fold truncation:

(a) only markets are considered as places of need satisfaction and resource management;

(b) all market activities are evaluated ex-post as efficient need satisfaction;

(c) only current value flows are relevant for welfare.

This explains that neoclassical economics measures success at all levels with monetary ratios: return on investment (ROI) for investments (micro level); financial profit for companies (meso level); and GDP for economies (macro level). Not only is it methodologically inappropriate to measure the increase of "welfare", "utility", or "happiness" with monetary ratios; according to Aristotle, such a scientific practice is not economics at all, but chrematistics. While the welfare of all is the goal in "oikonomia", the acquisition of money and the increase of capital are the goals of "chrematistiké" [63].

If one separates needs from strategies and applies a holistic understanding of the economy, financial indicators show systematic blind spots, and thus have a very questionable significance with regard to the starting point of economic activity, namely the satisfaction of needs. From the perspective of ECG, the direct measurement of welfare and its long-term resource base would be a more meaningful measure of the degree of permanently fulfilled needs. ECG therefore proposes to measure the common good with a 
multidimensional common good product (national economy), which is composed in extramarket, democratic processes. Pioneering concepts could be the doughnut [12], the concept of planetary boundaries contained therein, the gross national happiness (Bhutan) [64], or a sustainable wellbeing index [59]. Instead of the endless growth of material goods and consumption, they would most likely contain threshold values, both in terms of needs satisfaction, and ecological boundaries. With a common good balance sheet (companies) and a common good assessment (investments), the holistic measurement of the entrepreneurial contribution to welfare could be systematically derived from the common good product. The goal of doing business and the methods of measuring success would thus fit together.

\subsubsection{Markets and Welfare}

Markets are characterized, amongst other things, by freedom of enterprise, division of labor, and trade; but how do individual actions relate to overall welfare? In neoclassical welfare theory, the "invisible hand" has been one of the central hypotheses, according to which the utility-maximizing of individual actors unconsciously increases the common good. Necessary conditions for this are: the absence of power asymmetries, externalities, as well as complete information. If these conditions are not given, neoclassical economics speaks of market failure, which reduces welfare. However, this is assumed to be an exception while markets are generally thought to work efficiently [65]. As shown in the following sections, Sections 3.4.3-3.4.5, the exact definition of market failure cannot be found within market processes, so neoclassical economics lacks a method of systematically defining and estimating the extension of market failure.

\subsubsection{External Effects}

In principle, prices can only meet supply and demand efficiently if they reflect all relevant costs and benefits. If uninvolved third parties are also affected by an activity, then there are external costs (negative externalities) or benefits (positive externalities). The result is a discrepancy between the individual and the overall societal cost-benefit ratio [66]. The consequences are distorted prices, wrong incentives, inefficiencies, and welfare losses.

Neoclassical economics fundamentally assumes that prices reflect societal costs and benefits and treats externalities as exceptions, presumably as a result of the narrow market perspective on the economy. Since value is determined in neoclassical economics only via market-based willingness to pay, there is no method to systematically capture public goods and externalities. Given that numerous ecological, social, and interpersonal values are not expressed in monetary terms, and therefore appear neither in market prices nor in financial balance sheets, profit maximization, and the cost minimization necessary for it, lead systematically in markets to externalities such as soil degradation, climate change, health damage, or loss of trust $[67,68]$. Today, appropriate prices are the exception, and price-distorting externalities the rule. The holistic model of the ECG can systematically derive the public and common goods that are potentially affected by externalities from a democratically composed common good product.

The common good balance sheet derived from this (interpretable by neoclassical economics in the sense of an externalities balance) also captures the non-market and nonfinancial aspects of value creation. If the result of the common good balance is linked to, positive and negative, legal incentives, as proposed by the ECG, market prices can subsequently approximate the overall social costs and benefits. The challenge of direct cost internalization, e.g., via an enlarged accounting methodology, is that in many cases costs and benefits cannot be (clearly) determined in monetary terms. Therefore, the ECG pursues the approach of indirect internalization, with incentives linked to the common good balance sheet result. This means that the valuations of the various sub-aspects can be adjusted over time according to a price-standard approach until the respective social target values of the common good product are reached. This, still young, instrument undoubtedly needs further research and improvement. Moreover, the current common good balance 
sheet (Figure 2) sees itself, so far, only as a civil society preliminary stage of a democratically legitimized common good balance sheet [69].

\begin{tabular}{|c|c|c|c|c|}
\hline STAKEHOLDER & HUMAN DIGNITY & $\begin{array}{l}\text { SOLIDARITY AND } \\
\text { SOCIAL JUSTICE }\end{array}$ & $\begin{array}{l}\text { ENVIRONMENTAL } \\
\text { SUSTAINABILITY }\end{array}$ & $\begin{array}{l}\text { TRANSPARENCY AND } \\
\text { CO-DETERMINATION }\end{array}$ \\
\hline $\begin{array}{l}\text { A: } \\
\text { SUPPLIERS }\end{array}$ & $\begin{array}{l}\text { A1 Human dignity } \\
\text { in the supply chain }\end{array}$ & $\begin{array}{l}\text { A2 Solidarity and } \\
\text { social justice in the } \\
\text { supply chain }\end{array}$ & $\begin{array}{l}\text { A3 Environmental } \\
\text { sustainability in the } \\
\text { supply chain }\end{array}$ & $\begin{array}{l}\text { A4 Transparency and } \\
\text { co-determination in } \\
\text { the supply chain }\end{array}$ \\
\hline $\begin{array}{l}\text { B: } \\
\text { OWNERS, } \\
\text { EQUITY- AND } \\
\text { FINANCIAL SERVICE } \\
\text { PROVIDERS }\end{array}$ & $\begin{array}{l}\text { B1 Ethical position in } \\
\text { relation to financial } \\
\text { resources }\end{array}$ & $\begin{array}{l}\text { B2 Social position in } \\
\text { relation to financial } \\
\text { resources }\end{array}$ & $\begin{array}{l}\text { B3 Use of funds in } \\
\text { relation to social and } \\
\text { environmental impacts }\end{array}$ & $\begin{array}{l}\text { B4 Ownership and } \\
\text { co-determination }\end{array}$ \\
\hline $\begin{array}{l}\text { C: } \\
\text { EMPLOYEES, } \\
\text { INCLUDING } \\
\text { CO-WORKING } \\
\text { EMPLOYERS }\end{array}$ & $\begin{array}{l}\text { C1 Human dignity in the } \\
\text { workplace and working } \\
\text { environment }\end{array}$ & $\begin{array}{l}\text { C2 Self-determined } \\
\text { working arrangements }\end{array}$ & $\begin{array}{l}\text { C3 Environmentally- } \\
\text { friendly behaviour of } \\
\text { staff }\end{array}$ & $\begin{array}{l}\text { C4 Co-determination } \\
\text { and transparency within } \\
\text { the organisation }\end{array}$ \\
\hline $\begin{array}{l}\text { D: } \\
\text { CUSTOMERS AND } \\
\text { OTHER COMPANIES }\end{array}$ & $\begin{array}{l}\text { D1 Ethical customer } \\
\text { relations }\end{array}$ & $\begin{array}{l}\text { D2 Cooperation and } \\
\text { solidarity with other } \\
\text { companies }\end{array}$ & $\begin{array}{l}\text { D3 Impact on the } \\
\text { environment of the use } \\
\text { and disposal of products } \\
\text { and services }\end{array}$ & $\begin{array}{l}\text { D4 Customer } \\
\text { participation and } \\
\text { product transparency }\end{array}$ \\
\hline $\begin{array}{l}\text { E: } \\
\text { SOCIAL } \\
\text { ENVIRONMENT }\end{array}$ & $\begin{array}{l}\text { E1 Purpose of products } \\
\text { and services and their } \\
\text { effects on society }\end{array}$ & $\begin{array}{l}\text { E2 Contribution to the } \\
\text { community }\end{array}$ & $\begin{array}{l}\text { E3 Reduction of } \\
\text { environmental impact }\end{array}$ & $\begin{array}{l}\text { E4 Social } \\
\text { co-determination } \\
\text { and transparency }\end{array}$ \\
\hline
\end{tabular}

Figure 2. Matrix of the Common Good Balance Sheet.

\subsubsection{Complete Information}

Market participants can only make rational decisions if all relevant information is available. Neoclassical economics has a tendency to assume the ideal and regard deviations as exceptions, integrating the impact of incomplete information retrospectively, narrowing the perspective by only considering the benefits of products relevant for the end consumer. In contrast, the ECG model defines all social and environmental effects of value creation as relevant information, from its holistic understanding of economics and democratic concept of the common good. In practice, the common good balance sheet provides more complete information so that consumers can make rational and ethical decisions. The current regulatory trend in the EU towards mandatory disclosure of non-financial information supports the ECG approach.

\subsubsection{Power Asymmetries and Inequality}

Neoclassical economics tends to assume that all market transactions take place on a voluntary basis, often speaking of "free markets". Friedman states: "Since a household always has the alternative of producing directly for itself, it does not have to participate in the exchange (... ) Therefore, no exchange will take place unless both parties benefit from it. Cooperation is thus achieved without any coercion" [70]. In reality, almost two thirds of people are living in cities and thus do not have the alternative of "producing directly for themselves". The economy for the common good analyses market events in a principally different way. Above a certain level of inequality, power asymmetries characterize economic exchange relations. The average employer/lender/property manager/global corporation can withdraw from the employment contract/loan agreement/rental contract/supplier contract more easily than the average employee/borrower/tenant/supplier and thus determine the terms of the respective contract to a greater extent [71]. Common good economics expounds the problems of both the extent of power imbalances and the strategy of individual utility maximization, legitimized in economic education. Neoclassical economics also legitimizes unequal social relations with disproven assumptions such as the "trickle down" theory, the "rising tide lifts all boats" picture, or the Kuznets Curve: 
while Kuznets himself relativized his upside-down U as "pure guesswork", subsequent economists raised it "to the rank of a law" [72].

In terms of economic policy, this analysis leads to the establishment of world markets without merger control, unlimited accumulation of private assets, and free movement of capital without coordinated taxation. The result is a progressive concentration of wealth with the simultaneous experience of lack of freedom and coercion of the many. The current world economy relies on "positive (or reinforcing) feedback" in terms of distribution: the larger, wealthier, or more powerful a natural or legal person is, the easier it is for further growth. The economy for the common good, on the other hand, relies on "negative (or balancing) feedback": At the beginning, there should be support for career starters and company founders, after which progressive taxes and merger controls take effect until there is an absolute limit on the size of companies and inequality in income and wealth. This will keep power symmetries across all market participants in balance.

\subsubsection{Role of Democratic Institutions}

Neoclassical economists are often skeptical of the state: "Whenever a market solution to economic choice is possible $(\ldots)$ it is in principle preferable to resolve politically via majority decisions", teaches Ulrich van Suntum in his textbook [73]. In Mankiw/Taylor, the economic "principle" number six is: "Markets are usually a good way to organize economic activity" [74] (p. 8). An examination of Paul Samuelson's standard textbook revealed that he associates the term "state" almost exclusively with negative attributes and "market" exclusively with positive attributes [75]. Consequently, neoclassical economists have tended to favor liberalization and privatization, and have often opposed new regulations, even after the financial crisis of 2008.

Since the existence of many public goods probably derive from a democratically defined concept of the common good, the ECG model chooses a more balanced approach, and appreciates various functions of states, namely:

(d) creator, designer, and limiter of markets and economic freedoms;

(e) lawmaker and regulator: it determines the rules of the game;

(f) provider or guarantor of public goods and services;

(g) guarantor of social and public security.

Since markets can also be understood as the result of state infrastructures, from the protection of private property to the issuing of money to the provision of infrastructures of all kinds, the ECG rejects the term "intervention" and speaks instead of economic policy and "market design". The ECG recognizes the comprehensive primacy of politics over the economy. This includes the rules of the game, institutions, and infrastructures, as well as basic democratic and constitutional values. ECG thus confounds the glaring contradiction that values such as solidarity, sustainability, or human dignity are anchored in constitutions, while in economic education and political practice the primacy of competition, self-interest maximization, and limitless growth applies.

The state can and should be meaningfully economically active regarding services of general interest, infrastructure, and strategic goods, as well as basic research. Mariana Mazzucato has shown that many of the innovations that have emerged from state research projects and institutions have enabled private companies to develop new products and services in the first place [76]. Against this background, the ECG does not consider the state and the market as antagonists, but rather as synergists. In this regard, market and state are not separated, instead stable ecological and social framework conditions are seen as the core foundations of economic activity.

\subsubsection{Market Economy and Planetary Ecological Boundaries}

ECG takes the neoclassical definition of economics as "efficient management of scarce resources" seriously, but in view of the global environmental dangers it applies this primarily to ecological resources. In order to keep humanity's economic activity within ecological limits, it proposes ecological human rights, which are at the same time protective 
rights of nature. The annually renewable supply of biological resources would be divided among all living people and credited to their personal "environmental accounts", in the form of physical currency. In a two-step system, the poorest could sell that part of their ecological purchasing power for which they lack the financial means to the wealthier, allowing them to "land more softly" while the poor would receive an additional financial income: This exchange of "comparative purchase power advantages" would, similarly in terminology, but differently in content, from Ricardo, constitute a global socio-ecological win-win solution [14].

This is a fundamentally different approach from partially internalizing individual externalities through $\mathrm{CO}_{2}$ taxes or an emissions trading scheme, as it does not put a price on nature under the title "externality", but it concedes nature an intrinsic protection right, which limits economic freedoms and activities before they do harm. In addition, the social danger of developing an ecological two-class society due to pure price increases is averted. The solution proposed by the ECG model stems from the mindset that the planet and its fragile ecosystems are the basis of life and economic activity. This ecological view is fundamentally different to the anthropocentric neoclassical paradigm. ECG believes that this change of perspective and the adoption of ethics based on respect for nature is the basis for a good life, and ultimately the survival of humanity on this planet. (See Table 2).

Table 2. Comparison of neoclassical economics, common good economics, and economy for the common good (ECG) in an overview.

\begin{tabular}{|c|c|c|c|c|}
\hline & $\begin{array}{c}\text { Neoclassical } \\
\text { Economics Theoretical } \\
\text { Foundation }\end{array}$ & $\begin{array}{c}\text { Critical Analysis of } \\
\text { Neoclassical } \\
\text { Economics }\end{array}$ & $\begin{array}{c}\text { Common Good } \\
\text { Economics Theoretical } \\
\text { foundation }\end{array}$ & ECG Practical Model \\
\hline \multicolumn{5}{|l|}{$\begin{array}{l}1 \text { Philosophy } \\
\text { of Science }\end{array}$} \\
\hline 1.1 Scientific Genre & $\begin{array}{l}\text { "like" a natural science, } \\
\text { "truths", } \\
\text { "principles", "laws" }\end{array}$ & $\begin{array}{l}\text { Cultural norms and } \\
\text { free decisions ignored; } \\
\text { use of misguiding } \\
\text { metaphors }\end{array}$ & $\begin{array}{l}\text { Social science: markets } \\
\text { are cultural } \\
\text { constructions } \rightarrow \\
\text { "market design", } \\
\text { game rules }\end{array}$ & $\begin{array}{l}\text { Design and } \\
\text { reformability of } \\
\text { economic processes }\end{array}$ \\
\hline \multirow[t]{2}{*}{ 1.2 Epistemology } & $\begin{array}{c}\text { Pretension of } \\
\text { objectivity }\end{array}$ & $\begin{array}{l}\text { Lack of reflexivity, } \\
\text { ignorance of } \\
\text { pre-analytical vision, } \\
\text { selective perception }\end{array}$ & $\begin{array}{l}\text { Self-reflection, critical } \\
\text { realism, pragmatism }\end{array}$ & $\begin{array}{l}\text { basic issues of the } \\
\text { common good } \\
\text { democratically } \\
\text { discussed }\end{array}$ \\
\hline & $\begin{array}{l}\text { Positivist ideal of a } \\
\text { value-free science }\end{array}$ & $\begin{array}{l}\text { Implicit and thus } \\
\text { non-transparent values } \\
\text { and normativity }\end{array}$ & $\begin{array}{c}\text { Reflection and } \\
\text { transparency about } \\
\text { values }\end{array}$ & $\begin{array}{c}\text { Alignment of economic } \\
\text { activities with basic } \\
\text { values }\end{array}$ \\
\hline \multirow{2}{*}{ 1.3 Methods } & Mathematical methods & $\begin{array}{l}\text { Inappropriate for a } \\
\text { social science, } \\
\text { qualitative methods } \\
\text { neglected }\end{array}$ & $\begin{array}{l}\text { Plural methods } \\
\text { (quantitative and } \\
\text { qualitative) }\end{array}$ & $\begin{array}{c}\text { Organic, participatory, } \\
\text { discourse-oriented } \\
\text { processes }\end{array}$ \\
\hline & $\begin{array}{l}\text { Linear causalities, e.g., } \\
\text { methodological } \\
\text { individualism }\end{array}$ & $\begin{array}{l}\text { Complex systems } \\
\text { underestimated }\end{array}$ & $\begin{array}{l}\text { Holistic analysis of } \\
\text { complex systems with } \\
\text { system theory }\end{array}$ & $\begin{array}{l}\text { Definition of limits, } \\
\text { negative feedback } \\
\text { mechanisms }\end{array}$ \\
\hline 1.4 Inter-disciplinarity & Isolated discipline & $\begin{array}{l}\text { Findings of other } \\
\text { disciplines ignored }\end{array}$ & $\begin{array}{c}\text { Inter- and } \\
\text { trans-disciplinary } \\
\text { approach, "universal } \\
\text { science" }\end{array}$ & $\begin{array}{c}\text { Economy is not only } \\
\text { something for } \\
\text { economists }\end{array}$ \\
\hline
\end{tabular}


Table 2. Cont

\begin{tabular}{|c|c|c|c|c|}
\hline & $\begin{array}{c}\text { Neoclassical } \\
\text { Economics Theoretical } \\
\text { Foundation }\end{array}$ & $\begin{array}{c}\text { Critical Analysis of } \\
\text { Neoclassical } \\
\text { Economics }\end{array}$ & $\begin{array}{c}\text { Common Good } \\
\text { Economics Theoretical } \\
\text { foundation }\end{array}$ & ECG Practical Model \\
\hline \multicolumn{5}{|l|}{$\begin{array}{l}2 \text { Definition and Goal } \\
\text { of Economy and } \\
\text { Economics }\end{array}$} \\
\hline $\begin{array}{l}\text { 2.1 Definition and } \\
\text { goal of economy }\end{array}$ & $\begin{array}{l}\text { Economy as production } \\
\text { and trade activities } \\
\text { related to markets }\end{array}$ & $\begin{array}{l}\text { Reduced definition of } \\
\text { economy, inconsistent } \\
\text { with definition of } \\
\text { economics }\end{array}$ & $\begin{array}{c}\text { Economy as all } \\
\text { conscious activities to } \\
\text { satisfy (basic) human } \\
\text { needs }\end{array}$ & \multirow{2}{*}{$\begin{array}{l}\text { Need satisfaction and } \\
\text { the common good as } \\
\text { fundamental reference } \\
\text { to evaluate and } \\
\text { coordinate economic } \\
\text { activities }\end{array}$} \\
\hline $\begin{array}{l}\text { 2.2 Definition and } \\
\text { goal of economics }\end{array}$ & $\begin{array}{c}\text { Economics as the } \\
\text { science of "efficient } \\
\text { management of scarce } \\
\text { resources" }\end{array}$ & $\begin{array}{l}\text { No explicit reference } \\
\text { point, need satisfaction } \\
\text { and welfare only } \\
\text { implicit goals behind } \\
\text { decisions }\end{array}$ & $\begin{array}{l}\text { Economics as a science } \\
\text { of the efficient need } \\
\text { satisfaction and the } \\
\text { promotion of the } \\
\text { common good }\end{array}$ & \\
\hline \multicolumn{5}{|l|}{$\begin{array}{c}3 \text { Basic Elements of } \\
\text { Economy }\end{array}$} \\
\hline \multirow[t]{2}{*}{ 3.1 Concept of Needs } & $\begin{array}{l}\text { Equalization of } \\
\text { preferences and needs }\end{array}$ & $\begin{array}{l}\text { Equalization can lead } \\
\text { to target-missing } \\
\text { inefficiency, reinforced } \\
\text { by advertising }\end{array}$ & $\begin{array}{l}\text { Basic needs are defined; } \\
\text { preferences are } \\
\text { culturally variable }\end{array}$ & $\begin{array}{l}\text { Products serve needs, } \\
\text { induced by the } \\
\text { Common Good Balance } \\
\text { Sheet }\end{array}$ \\
\hline & Unlimited needs & $\begin{array}{l}\text { Falsified by happiness } \\
\text { research; }\end{array}$ & $\begin{array}{l}\text { Limited/saturable } \\
\text { needs; } \\
\text { unlimited strategies }\end{array}$ & $\begin{array}{l}\text { Efficient welfare level; } \\
\text { restrictions to } \\
\text { advertising }\end{array}$ \\
\hline \multirow{3}{*}{ 3.2 Conceptionof Man } & & & & $\begin{array}{l}\text { Value-based education } \\
\text { promotes: }\end{array}$ \\
\hline & $\begin{array}{l}\text { Homo economicus: } \\
\text { purpose-rational = } \\
\text { egoistic = capitalistic }\end{array}$ & $\begin{array}{c}\text { Value-rational, affective } \\
\text { and traditional } \\
\text { behavior is ignored }\end{array}$ & $\begin{array}{l}\text { multidimensionality of } \\
\text { humans includes } \\
\text { empathy, care, and } \\
\text { responsibility }\end{array}$ & $\begin{array}{ll}- & \text { humanistic man- } \\
\text { agement } \\
-\quad & \text { responsible } \\
& \text { consumption } \\
- & \text { impact investing }\end{array}$ \\
\hline & $\begin{array}{l}\text { Between axiom and } \\
\text { hypothesis }\end{array}$ & $\begin{array}{l}\text { Tautological axiom or } \\
\text { implicitly normative } \\
\text { hypothesis }\end{array}$ & $\begin{array}{l}\text { Implicit normativity of } \\
\text { concept of man is made } \\
\text { explicit }\end{array}$ & $\begin{array}{l}\text { Reflection of diverse } \\
\text { concepts of man in } \\
\text { economic education }\end{array}$ \\
\hline 3.3 Resources & $\begin{array}{c}\text { Focus on labor, capital } \\
\text { and land; high } \\
\text { substitutability } \\
\text { of resources }\end{array}$ & $\begin{array}{l}\text { Functional hierarchies } \\
\text { and tipping points are } \\
\text { ignored }\end{array}$ & $\begin{array}{l}\text { Includes natural, social, } \\
\text { human, and built } \\
\text { capital; } \\
\text { complementary and } \\
\text { limited resources }\end{array}$ & $\begin{array}{l}\text { Framework and } \\
\text { thresholds for balanced } \\
\text { resource mix }\end{array}$ \\
\hline $\begin{array}{l}3.4 \text { Types of goods } \\
\text { and property }\end{array}$ & $\begin{array}{l}\text { Focus on private goods, } \\
\text { public goods a } \\
\text { minor issue }\end{array}$ & $\begin{array}{l}\text { Public and common } \\
\text { goods, commons are } \\
\text { underestimated }\end{array}$ & $\begin{array}{l}\text { Variable and diverse } \\
\text { forms of goods, with } \\
\text { limits and conditions }\end{array}$ & $\begin{array}{l}\text { Coexistence of private, } \\
\text { public, and collective } \\
\text { types of property; } \\
\text { protection rights } \\
\text { of nature }\end{array}$ \\
\hline $\begin{array}{l}\text { 3.5 Places of the } \\
\text { economy }\end{array}$ & $\begin{array}{l}\text { Markets as the only } \\
\text { relevant place of need } \\
\text { satisfaction }\end{array}$ & $\begin{array}{l}\text { Other places like public } \\
\text { goods, commons or } \\
\text { households are } \\
\text { downplayed }\end{array}$ & $\begin{array}{l}\text { All places of need } \\
\text { satisfaction are } \\
\text { considered on an equal } \\
\text { footing }\end{array}$ & $\begin{array}{l}\text { All economic activities } \\
\text { are included in the } \\
\text { measurement of the } \\
\text { common good }\end{array}$ \\
\hline
\end{tabular}


Table 2. Cont.

\begin{tabular}{|c|c|c|c|c|}
\hline & $\begin{array}{c}\text { Neoclassical } \\
\text { Economics Theoretical } \\
\text { Foundation }\end{array}$ & $\begin{array}{c}\text { Critical Analysis of } \\
\text { Neoclassical } \\
\text { Economics }\end{array}$ & $\begin{array}{c}\text { Common Good } \\
\text { Economics Theoretical } \\
\text { foundation }\end{array}$ & ECG Practical Model \\
\hline \multicolumn{5}{|l|}{$\begin{array}{l}4 \text { Welfare and Market } \\
\text { Economy }\end{array}$} \\
\hline \multirow{2}{*}{$\begin{array}{l}\text { 4.1 Concept and } \\
\text { measurement }\end{array}$} & $\begin{array}{l}\text { Deductive definition by } \\
\text { economists }\end{array}$ & $\begin{array}{c}\text { Selective definition } \\
\text { without well-grounded } \\
\text { legitimization }\end{array}$ & $\begin{array}{l}\text { Procedural definition } \\
\text { through democratic } \\
\text { decision }\end{array}$ & $\begin{array}{c}\text { Democratic } \\
\text { conventions to identify } \\
\text { components }\end{array}$ \\
\hline & $\begin{array}{c}\text { Monetary } \\
\text { measurement with } \\
\text { GDP; endless growth } \\
\text { as goal }\end{array}$ & $\begin{array}{l}\text { Non-monetary aspects } \\
\text { are ignored } \rightarrow \text { e.g., } \\
\text { ecological boundaries } \\
\text { are overlooked }\end{array}$ & $\begin{array}{l}\text { Multidimensional } \\
\text { consideration; } \\
\text { trade-offs resolved } \\
\text { through threshold } \\
\text { values }\end{array}$ & $\begin{array}{c}\text { Common good product } \\
\text { as a multidimensional } \\
\text { compass }\end{array}$ \\
\hline 4.2 Market economy & $\begin{array}{c}\text { Market failure is } \\
\text { exception, efficient } \\
\text { equilibria are the norm }\end{array}$ & $\begin{array}{l}\text { Market failure occurs } \\
\text { regularly, but no } \\
\text { method to capture it } \\
\text { systematically }\end{array}$ & $\begin{array}{l}\text { Market failure is } \\
\text { derived from/captured } \\
\text { by common good } \\
\text { product and prevented } \\
\text { by market design }\end{array}$ & $\begin{array}{l}\text { Complete information } \\
\text { and cost internalization; } \\
\text { small power } \\
\text { asymmetries }\end{array}$ \\
\hline $\begin{array}{l}4.3 \text { Complete } \\
\text { information }\end{array}$ & $\begin{array}{l}\text { Focus on price- } \\
\text { performance-ratio of } \\
\text { final product }\end{array}$ & $\begin{array}{c}\text { Non-market } \\
\text { information remains } \\
\text { unconsidered }\end{array}$ & $\begin{array}{l}\text { Complete information } \\
\text { of all ethical side-effects } \\
\text { of production }\end{array}$ & $\begin{array}{l}\text { Common good balance } \\
\text { sheet provides full } \\
\text { transparency }\end{array}$ \\
\hline 4.4 External Effects & $\begin{array}{l}\text { External effects as } \\
\text { exceptions }\end{array}$ & $\begin{array}{l}\text { Unsystematic, } \\
\text { incomplete } \\
\text { identification }\end{array}$ & $\begin{array}{l}\text { Systematic derivation } \\
\text { and identification of } \\
\text { external effects }\end{array}$ & $\begin{array}{c}\text { Complete } \\
\text { internalization with } \\
\text { common good balance } \\
\text { Sheet and incentives }\end{array}$ \\
\hline $\begin{array}{l}4.5 \text { Power and } \\
\text { inequality }\end{array}$ & $\begin{array}{l}\text { Complete competition } \\
=\text { rule; excessive power } \\
=\text { exception }\end{array}$ & $\begin{array}{l}\text { Power asymmetries } \\
\text { and positive feedback } \\
\text { mechanisms } \\
\text { underestimated }\end{array}$ & $\begin{array}{l}\text { Market design, with } \\
\text { negative feedback } \\
\text { mechanisms, prevents } \\
\text { power concentration }\end{array}$ & $\begin{array}{l}\text { Progressive taxes, size } \\
\text { limits for companies, } \\
\text { fusion control }\end{array}$ \\
\hline $\begin{array}{l}\text { 4.6 Democratic } \\
\text { institutions }\end{array}$ & $\begin{array}{c}\text { Free market as ideal; } \\
\text { state action = inefficient } \\
\text { as a rule }\end{array}$ & $\begin{array}{l}\text { "Free market" is } \\
\text { undefined myth; } \\
\text { institutional } \\
\text { prerequisites ignored }\end{array}$ & $\begin{array}{l}\text { State institutions are } \\
\text { legal infrastructure and } \\
\text { thus inseparable } \\
\text { elements of markets }\end{array}$ & $\begin{array}{l}\text { Growing set of } \\
\text { regulatory bodies } \\
\text { including strong global } \\
\text { governance }\end{array}$ \\
\hline $\begin{array}{l}4.7 \text { Planetary } \\
\text { boundaries }\end{array}$ & $\begin{array}{l}\text { Not part of theory; } \\
\text { partly regarded as } \\
\text { non-economic issues }\end{array}$ & $\begin{array}{c}\text { Dissociation turns } \\
\text { "autistic" economics } \\
\text { into a danger for } \\
\text { humanity }\end{array}$ & $\begin{array}{l}\text { Part of the definition of } \\
\text { economy and thus } \\
\text { inherent limits of } \\
\text { economic activities }\end{array}$ & $\begin{array}{l}\text { Ecological human } \\
\text { rights: personal, } \\
\text { equal environmental } \\
\text { accounts }\end{array}$ \\
\hline
\end{tabular}

\section{Discussion}

Discussions about both an appropriate economic theory, and a practical model supporting the common good have always been present through the history of thought. Over the last 150 years, neoclassical economics and its practical conclusion towards a liberal, capitalistic market economy have progressively dominated this discussion.

Neoclassical economics has certainly made a great contribution to the analysis of economic processes. Nevertheless, in crucial points it has major shortcomings which no longer do justice to the complexity of the real world of the 21st century. Namely, the vision of itself as a natural science leads to inadequate mathematical methods, leading to an extremely narrow view of human behavior, need satisfaction, and economic activity in general.

It is true that singular aspects have been integrated subsequently, which shows that gaps were recognized, and led to the further development of the incomplete theory $[77,78]$. The discussion about how to measure welfare shows the emergence of new perspectives and insights in economic mainstream theory [38]. Behavioral economics have questioned and 
partly adapted the rationality concept [79]. Environmental economics is a growing branch in neoclassical theory, strengthening a discussion about natural capital accounting [80].

In this process, however, theoretical inconsistencies occur because new elements are often only placed as additions alongside existing theories, without systematically revising the basic assumptions ("market laws", substitutability of capital, economics as pure market activity, rationality concept, unlimited needs) and practical conclusions (e.g., free markets, profit maximization, competition, endless growth of GDP), which are thereby called into question, and without clarifying sufficiently the relationship to new findings. Thus, especially in introductory textbooks, incomplete and contradictory theories are widespread, and thereby misleading for future generations of economists.

This view is supported by a broad and growing literature. An in-depth scrutiny of microeconomics and macroeconomics textbooks has been made by Helge Peukert [81,82]. In the German area, heterodox economists have published several anthologies which cover many of the aspects included in our research $[83,84]$. Important single contributions have been made by Daly and Cobb Jr. [85], Keen [86], Raworth [12], Rogall [87], Priem et al. [88], Ötsch [89], and others.

As for the proper term "common good economics", we found some authors from different language areas who used similar terms. As early as 1989, Herman Daly and John Cobb Jr. published "For the Common Good" [85]. The Italian economist Stefano Zamagni published "L'economia del bene comune" in 2007 [90]. Together with Luigino Bruni, he previously published (2004) "Economia civile", and after (2015) "L'economia civile", which was translated into Spanish as "Por una economía del bien común" (2012), and into English as "Civil Economy" (2016). Finally, the French economist Jean Tirole published "Économie du bien commun" in 2016, which was translated into English as "economics for the common good" in 2017 [91].

Common good economics, as portrayed here for the first time systematically, certainly has some intersections with the previously named concepts. However in its reach and key concepts it needs to be understood as a separate approach. A detailed comparison is unfortunately out of the scope of this article.

Common good economics here presented reveals some fundamental differences in comparison with neoclassical economics (Table 2), and points to a more holistic, integrated, and contradiction-free path. It strongly builds on various heterodox approaches, such as ecological economics [11] and sustainable economics [87], following their approach of an socially and ecologically embedded economy. Due to its interdisciplinary approach to the object of research, it also builds on a broad range of contributions from non-economist disciplines such as ecology, psychology, and sociology.

In some areas, the introduced common good economics offers a theoretical extension of neoclassical economics (object of study, conception of man, concept and measurement of welfare), whereas in other areas it represents a consistent and systematically integrated implementation of neoclassical theoretical claims (integrated solution for market failures). In this respect, common good economics can be understood in this first brief analysis as both a further development of neoclassical economics, and its fundamental transcendence.

New practical ideas of the ECG model, for example, the common good balance sheet, the common good product, and the concept of ethical world trade or ecological human rights, can be derived from or embedded in this theoretical framework of common good economics. However, they must prove themselves in practice. Especially, the common good balance sheet needs to be further compared with other sustainability reporting frameworks [92]. Besides, it must prove to be in line with a democratic understanding of common good [69]; this is in line with the pragmatist theoretical understanding of ECG.

\section{Conclusions}

On a theoretical level, a large amount of criticism of neoclassical economics has been made over the years. Most probably, an economic model building on the neoclassical economic approach will fail to meet the ecological and social global challenges of the 21st 
century. Several heterodox schools have evolved and exist, but mostly do not communicate with the "mainstream" at eye level. Despite many contradictions and falsifications of many of its assumptions and core elements, neoclassical economics is still the mainstream in economics.

On a practical level the ECG model offers holistic solutions for the challenges mentioned above, and meets a growing interest in economic practice. However, it has not so far considered itself a theoretical school of economics.

Our contribution to both strengthening a realistic economic theory and integrating the practical ECG model into theoretical discussions is twofold: first, an explication of the theoretical foundations of the economy for the common good; and second, a systematic comparison of the resulting common good economics with neoclassical economics.

Thanks to this first article, the cornerstone of a theoretical base of the ECG model, "common good economics", has been laid, translating some of its basic assumptions into existing scientific concepts and language, ready for perception and discussion. On this very foundation, the ECG model can be systematically compared to neoclassical economics and other theoretical schools, and is now ready for scientific discourse and further development.

The evaluation of which model is more fit to cope with the challenges for mankind in the 21st century is up to subsequent empirical research, and a broad discourse within the scientific community.

Author Contributions: Conceptualization, methodology, formal analysis, investigation, resources, writing-review and editing, J.D. and C.F.; visualization, J.D.; writing—original draft preparation: all authors; supervision, P.T.; project administration, C.F. All authors have read and agreed to the published version of the manuscript.

Funding: This research received no external funding.

Institutional Review Board Statement: Not applicable.

Informed Consent Statement: Not applicable.

Data Availability Statement: No new data were created or analyzed in this study. Data sharing is not applicable to this article.

Acknowledgments: We want to thank the ECG movement, especially its science hub, and all the contributors to the scientific debate and creation of a new, more comprehensive and holistic paradigm for the economy and economics.

Conflicts of Interest: The authors declare no conflict of interest.

\section{References}

1. WBGU. Civilisational Progress within Planetary Guard Rails, A Contribution to the SDG Debate; Policy Paper 8; WBGU: Bowling Green, OH, USA, 2014.

2. WFP. Risk of Hunger Pandemic as Coronavirus Set to Almost Double Acute Hunger by End of 2020. Available online: https:/ / www.wfp.org/stories/risk-hunger-pandemic-coronavirus-set-almost-double-acute-hunger-end-2020 (accessed on 31 December 2020).

3. Halbmeier, C.; Grabka, M.M. Vermögensungleichheit in Deutschland bleibt trotz deutlich steigender Nettovermögen anhaltend hoch. DIW Wochenbericht 2019, 40, 739.

4. Felber, C. Gemeinwohl-Ökonomie; Piper: Munich, Germany, 2018; p. 95.

5. Wilkinson, R.G. Sick Societies. Social Equilibrium and Health; The New Press: New York, NY, USA, $2005 ;$ p. 300.

6. Kasser, T. The High. Price of Materialism; MIT Press: Cambridge, MA, USA, 2002.

7. Lawson, T. What is this 'school' called neoclassical economics? Camb. J. Econ. 2013, 37, 947-983. [CrossRef]

8. Arnsberger, C.; Varoufakis, Y. What is Neoclassical Economics? The three axioms responsible for its theoretical oeuvre, practical irrelevance and, thus, discursive power. Panoeconomicus 2006, 1, 5-18. [CrossRef]

9. Mankiw, N.G.; Taylor, M.P. Grundzüge der Volkswirtschaftslehre, 7th ed.; Schäffer-Poeschel: Stuttgart, Germany, 2018 ; p. 24.

10. Schneidewind, U.; Pfriem, R.; Barth, J.; Beschorner, T.; Binswanger, M.; Diefenbacher, H.; Eisenack, K.; Elsen, S.; Goldschmidt, N.; Graupe, S.; et al. Transformative Wirtschaftswissenschaft im Kontext nachhaltiger Entwicklung. Ökologisches Wirtschaften 2016, 31, 30-34. [CrossRef]

11. Costanza, R.; Cumberland, J.H.; Daly, H.; Goodland, R.; Norgaard, R.B.; Kubiszewski, I.; Franco, C. An Introduction to Ecological Economics, 2nd ed.; CRC Press: Boca Raton, FL, USA; New York, NY, USA; London, UK, 2015. 
12. Raworth, K. Doughnut Economics. Seven Ways to Think Like a 21st-Century-Economist; Random House Business Books: London, UK, 2017.

13. Rogall, H. Grundlagen einer Nachhaltigen Wirtschaftslehre, 2nd ed.; Metropolis: Marburg, Germany, 2015.

14. Felber, C. Change Everything. Creating an Economy for the Common Good; Zed Books: London, UK, 2015; pp. 210-212.

15. Economy for the Common Good. Available online: https://www.ecogood.org/ (accessed on 30 December 2020).

16. Mankiw, N.G.; Taylor, M.P. Grundzüge der Volkswirtschaftslehre, 5th ed.; Schäffer-Poeschel: Stuttgart, Germany, 2012; p. VIII.

17. Walras, L. Elements of Pure Economics: Or, The Theory of Social Wealth; American Economic Association and Royal Economic Society: London, UK, 1954; p. 71.

18. Allais, M. An Outline of my Main Contributions to Economic Science; Nobel Lecture: Stockholm, Sweden, 1988 ; p. 243.

19. Friedman, M. The Methodology of Positive Economics. In Essays in Positive Economics; University of Chicago Press: Chicago, IL, USA, 1966; p. 4.

20. Straubhaar, T. End the imperialism of economists. Financial Times Deutschland, 5 March 2012.

21. Samuelson, P.A.; Nordhaus, W.D. Economics, 19th ed.; McGraw-Hill/Irwin: New York, NY, USA, 2010; p. xviii.

22. Mankiw, N.G.; Taylor, M.P. Grundzüge der Volkswirtschaftslehre, 7th ed.; Schäffer-Poeschel: Stuttgart, Germany, 2018 ; p. 3.

23. Keen, S. Debunking Economics: The Naked Emperor Dethroned? Zed Books: London, UK; New York, NY, USA, $2011 ;$ p. 73.

24. Schumpeter, J.A. History of Economic Analysis; University Press: New York, NY, USA, 1954; p. 41.

25. Komlos, P. Ökonomisches Denken Nach dem Crash. Einführung in eine Realitätsbasierte Volkswirtschaftslehre; Houghton Mifflin Company: Boston, MA, USA; New York, NY, USA, 2015; p. 55.

26. Davis, J.B. Keynes's View of Economics as a Moral Science. In Keynes and Philosophy: Essays on the Origins of Keynes's Thought; Baeteman, B.W., Davis, J.B., Eds.; Edward Elgar Publishing: Cheltenham, UK, 1991; p. 89.

27. Kirchgässner, G. In: C. von Rechenberg: VWL in der Krise. What is the lesson? ZDF Info, 15 November 2011 ; p. 1.

28. Stiglitz, J. Where Modern Macroeconomics Went Wrong; NBER Working Paper 23795; NBER: Cambridge, MA, USA, $2017 ;$ p. 21.

29. Rockström, J.; Steffen, W.; Noone, K.; Persson, A.; Chapin, F.S., III; Lanbin, E.; Lenton, T.M.; Scheffer, M.; Folke, C.; Schellnhuber, H.J.; et al. Planetary Boundaries: Exploring the Safe Operating Space for Humanity. Nature 2009, 461, $472-475$. [CrossRef] [PubMed]

30. Felber, C. This is Not Economy. Aufruf zur Revolution der Wirtschaftswissenschaft; Deuticke: Vienna, Austria, 2019 ; pp. 42-44.

31. Post-Autistic Economics Network. Available online: http://www.paecon.net/HistoryPAE.htm (accessed on 30 December 2020).

32. Fourcade, M.; Ollion, E.; Algan, Y. The Superiority of Economics. J. Econ. Perspect. 2015, 29, 95. [CrossRef]

33. Komlos, P. Ökonomisches Denken nach dem Crash. Einführung in eine realitätsbasierte Volkswirtschaftslehre; Houghton Mifflin Company: Boston, MA, USA; New York, NY, USA, 2015.

34. Oswald, A.; Stern, N. Why are economists letting the world down on climate change? voxeu.org, 17 September $2019 ;$ p. 1.

35. Felber, C. This is Not Economy. Aufruf zur Revolution der Wirtschaftswissenschaft; Deuticke: Vienna, Austria, 2019 ; pp. $255-268$.

36. Mankiw, N.G.; Taylor, M.P. Grundzüge der Volkswirtschaftslehre, 7th ed.; Schäffer-Poeschel: Stuttgart, Germany, 2018 ; p. 2.

37. Dierksmeier, D. Reframing Economic Ethics. The Philosophical Foundations of Humanistic Management; Palgrave Macmillan: Cham, Switzerland, 2016; p. 35.

38. Stiglitz, J.; Sen, A.; Fitoussi, J.-P. Report by the Commission on the Measurement of Economic Performance and Social Progress; Commission on the Measurement of Economic Performance and Social Progress: Paris, France, 2009.

39. Felber, C. This is Not Economy. Aufruf zur Revolution der Wirtschaftswissenschaft; Deuticke: Vienna, Austria, 2019 ; p. 258.

40. Mankiw, N.G.; Taylor, M.P. Grundzüge der Volkswirtschaftslehre, 7th ed.; Schäffer-Poeschel: Stuttgart, Germany, $2018 ;$ p. 127.

41. Mankiw, N.G.; Taylor, M.P. Grundzüge der Volkswirtschaftslehre, 7th ed.; Schäffer-Poeschel: Stuttgart, Germany, 2018 ; pp. 231-233.

42. Mankiw, N.G.; Taylor, M.P. Grundzüge der Volkswirtschaftslehre, 7th ed.; Schäffer-Poeschel: Stuttgart, Germany, $2018 ;$ p. 137.

43. Varian, H.R. Grundzüge der Mikroökonomik, 9th ed.; De Gruyter: Berlin, Germany; Boston, MA, USA, 2016 ; p. 36.

44. Mankiw, N.G.; Taylor, M.P. Grundzüge der Volkswirtschaftslehre, 7th ed.; Schäffer-Poeschel: Stuttgart, Germany, 2018 ; p. 130.

45. Samuelson, P.A.; Nordhaus, W.D. Volkswirtschaftslehre. Das internationale Standardwerk der Makro- und Mikroökonomie, 3rd updated ed.; mi-Fachverlag: Landsberg am Lech, Germany, 2007; p. 21.

46. Neef, M.M. Human Scale Development. Conception, Application and Further Reflections; The Appex Press: New York, NY, USA; London, UK, 1991; pp. 29-37.

47. Gough, I. Climate Change and Sustainable Welfare: The Centrality of Human Needs. Camb. J. Econ. 2015, 39, 1191-1214. [CrossRef]

48. Rauschmeyer, F.; Omann, I. Need as a Central Element of Sustainable Development. In Routledge Handbook of Ecol. Econ.; Spash, C.L., Ed.; Routledge: New York, NY, USA, 2017; pp. 246-255.

49. Mankiw, N.G.; Taylor, M.P. Grundzüge der Volkswirtschaftslehre, 7th ed.; Schäffer-Poeschel: Stuttgart, Germany, 2018 ; p. 128.

50. Sen, A.K. Rational Fools: A Critique of the Behavioral Foundations of Economic Theory. Philos. Public Aff. 1977, 6, 336.

51. Weber, M. Wirtschaft und Gesellschaft; Zweitausendeins: Frankfurt, Germany, 2005; p. 27.

52. Faber, M.; Petersen, T.; Schiller, J. Homo Oeconomicus and Homo Politicus in Ecological Economics. Ecol. Econ. 2002, 40, 323-333. [CrossRef]

53. Flieger, U. Homo communitas. Die fundamental-theoretische Evolution in der GWÖ. Zeitschrift für Wirtschafts- und Unternehmensethik 2019, 20, 427-442. [CrossRef] 
54. Bastien, C.; Cardoso, J.L. From homo economicus to homo corporativus: A neglected critique of neoclassical economics. J. Soc. Econ. 2007, 36, 118-127. [CrossRef]

55. Siebenhüner, B. Homo Sustinens. Auf dem Weg zu einem Menschenbild der Nachhaltigkeit; Metropolis-Verlag: Marburg, Germany, 2001.

56. Felber, C. This is Not Economy. Aufruf zur Revolution der Wirtschaftswissenschaft; Deuticke: Vienna, Austria, 2019; p. 115f.

57. Raworth, K. Doughnut Economics. Seven Ways to Think Like a 21st-Century-Economist; Random House Business Books: London, UK, 2017; p. 100.

58. Mankiw, N.G.; Taylor, M.P. Grundzüge der Volkswirtschaftslehre, 7th ed.; Schäffer-Poeschel: Stuttgart, Germany, $2018 ;$ p. 176.

59. Costanza, R.; Daly, L.; Fioramonti, L.; Giovannini, E.; Kubiszewski, I.; Mortensen, L.F.; Pickett, K.E.; Agnarsdottir, K.V.; De Vogli, R.; Wilkinson, R. Modelling and measuring sustainable wellbeing in connection with the UN Sustainable Development Goals. Ecol. Econ. 2016, 130, 350-355. [CrossRef]

60. Mankiw, N.G.; Taylor, M.P. Grundzüge der Volkswirtschaftslehre, 7th ed.; Schäffer-Poeschel: Stuttgart, Germany, 2018 ; p. 304.

61. Helfrich, S.; Bollier, D. Frei, Fair und Lebendig. Die Macht der Commons; Transcript: Bielefeld, Germany, 2019.

62. Goodwin, N.; Harris, J.; Nelson, J.A.; Roach, B.; Torras, M. Principles of Economics in Context; Routledge: London, UK; New York, NY, USA, 2014; p. 43.

63. Dierksmeier, C.; Pirson, M. Oikonomia Versus Chrematistike, Learning from Aristotle About the Future Orientation of Business Management. J. Bus. Ethics 2009, 88, 417-430. [CrossRef]

64. Ha Vinh, T. Der Glücksstandard: Wie wir Bhutans Bruttonationalglück praktisch umsetzen können; O. W. Barth Verlag: Munich, Germany, 2019.

65. Mankiw, N.G. Grundzüge der Volkswirtschaftslehre, 3rd ed.; Schäffer-Poeschel: Stuttgart, Germany, $2004 ;$ p. 169.

66. Fritsch, M. Marktversagen und Wirtschaftspolitik. Mikroökonomische Grundlagen staatliches Handelns; Vahlen: Munich, Germany, 2014 ; p. 82.

67. Stern, N. The Economics of Climate Change. The Stern Review; Cambridge University Press: Cambridge, UK, 2007.

68. Trucost. Natural Capital at Risk. The top 100 Externalities of Business; Trucost: London, UK, 2013.

69. Meynhardt, T.; Jasinenko, A.; Grubert, T. For a critique of the legitimacy of the Common Good Balance sheet. Die GemeinwohlBilanz auf dem Prüfstand der Bevölkerung. Empirische Überprüfung der demokratischen Legitimation der Gemeinwohl-Bilanz. ZFWU 2019, 20, 406-426. [CrossRef]

70. Friedman, F. Kapitalismus und Freiheit, 3rd ed.; Piper: Munich, Germany, 2006; p. 36.

71. Felber, C. Neue Werte für die Wirtschaft. Eine Alternative zu Kommunismus und Kapitalismus; Deuticke: Vienna, Austria, 2008 ; p. 22.

72. Fogel, R.W. Some Notes on the Scientific Methods of Simon Kuznets; Working Paper, No. 2461; National Bureau of Economic Research: Cambridge, MA, USA, 1987; pp. 26-27.

73. Van Suntum, U. Die unsichtbare Hand. Ökonomisches Denken gestern und heute, 5th ed.; Springer Gabler: Wiesbaden, Germany, 2013; p. 256.

74. Mankiw, N.G.; Taylor, M.P. Grundzüge der Volkswirtschaftslehre, 7th ed.; Schäffer-Poeschel: Stuttgart, Germany, 2018 ; p. 8.

75. Graupe, S. Beeinflussung und Manipulation in der ökonomischen Bildung. Hintergründe und Beispiele; FGW-Studie Neues Ökonomisches Denken 05: Düsseldorf, Germany, 2017; pp. 54-55.

76. Mazzucato, M. The Entrepreneurial State: Debunking Public vs. Private Sector Myths; Penguin: London, UK, 2018.

77. Colander, D.; Holt, R.; Rosser, B. The Changing Face of Mainstream Economics. Rev. Politic. Econ. 2004, 16, 485-500. [CrossRef]

78. Lowenberg, A.D. Neoclassical Economics as a Theory of Politics and Institutions. Cato J. 1990, 9, 619-639.

79. Kahnemann, D. Thinking Fast and Slow; Penguin Books: London, UK, 2012.

80. Sukhdev, P.; Wittmer, H.; Schröter-Schlaack, C.; Neßhöver, C.; Bishop, J.; Brink, P.T.; Gundimeda, H.; Kumar, P.; Simmons, B. The Economics of Ecosystems \& Biodiversity. Mainstreaming the Economics of Nature. A Synthesis of the Approach, Conclusions and Recommendations of TEEB. Available online: http:/ / teebweb.org/wp-content/uploads/Study\%20and\%20Reports/Reports/ Synthesis\%20report/TEEB\%20Synthesis\%20Report\%202010.pdf (accessed on 29 January 2021).

81. Peukert, H. Mikroökonomische Lehrbücher: Wissenschaft oder Ideologie? Metropolis: Marburg, Germany, 2018.

82. Peukert, H. Makroökonomische Lehrbücher: Wissenschaft oder Ideologie? Metropolis: Marburg, Germany, 2018.

83. Dürmeier, T.; Von Egan-Krieger, T.; Peukert, H. Die Scheuklappen der Wirtschaftswissenschaft. Postautistische Ökonomik für Eine Plurale Wirtschaftslehre; Metropolis: Marburg, Germany, 2006.

84. Van Treek, T.; Urban, J. Wirtschaft neu Denken. Blinde Flecken der Lehrbuchökonomie; iRights.Media: Berlin, Germany, 2016.

85. Daly, H.E.; Cobb, J.B. For the Common Good. Redirecting the Economy toward Community, the Environment, and a Sustainable Future, 2nd revised ed.; Beacon Press: Boston, MA, USA, 1994.

86. Keen, S. Debunking Economics: The Naked Emperor Dethroned? Zed Books: London, UK; New York, NY, USA, 2011.

87. Rogall, H. Grundlagen einer Nachhaltigen Volkswirtschaftslehre. Volkswirtschafts für Studierende des 21. Jahrhunderts, 2nd revised ed.; Metropolis: Marburg, Germany, 2015.

88. Pfriem, R.; Schneidewind, U.; Barth, J.; Graupe, S.; Korbun, T. (Eds.) Transformative Wirtschaftswissenschaft im Kontext Nachhaltiger Entwicklung; Metropolis: Marburg, Germany, 2017.

89. Ötsch, W.O. Mythos Markt. Mythos Neoklassik. Das Elend des Marktfundamentalismus; Metropolis: Marburg, Germany, 2018.

90. Zamagni, S. Economia del Bene Commune; Città Nuova: Rome, Italy, 2007. 
91. Tirole, J. Economics for the Common Good; Princeton University Press: Princeton, NJ, USA, 2017.

92. Brockhoff, D.; Engelhardt, G.; Yabroudi, H.; Karg, L.; Aschenbrenner, A.; Felber, C. Publizitätspflicht zur Nachhaltigkeit. Entwicklung eines Anforderungskatalogs für einen Universellen Standard (PuNa-Studie); IASS: Potsdam, Germany, 2020. 